\title{
SEISMIC PERFORMANCE OF R C BUILDINGS ON SLOPING GROUNDS WITH DIFFERENT TYPES OF BRACING SYSTEMS
}

\author{
Manjunath C S $\mathbf{S}^{\mathbf{1}}$, Siddu Karthik $\mathbf{C} \mathbf{S}^{\mathbf{2}}$ \\ ${ }^{1}$ Assistant Professor, Department of CIVIL, Vijaya Vittala Institute of Technology, Bengaluru, India \\ vbspmanju@gmail.com \\ ${ }^{2}$ Assistant Professor, Department of CIVIL, Vijaya Vittala Institute of Technology, Bengaluru, India \\ siddu2804@gmail.com
}

\begin{abstract}
Structure are highly susceptible to serve damages in earthquake scenario, so choosing an appropriate lateral force resisting bracing systems will have a significant effect on performance of the structure. So this present study is aimed at evaluating and comparing various types of eccentric steel bracings for 12 storey $R C$ frame building resisting on sloping ground configurations. For this 5 types of bracing systems like X-Bracing, Diagonal bracing, $K$ - bracing, V-bracing and inverted $V$ bracing are considered on the outer periphery of the buildings with step back and set back - step back type configurations are modeled and analyzed. The models are compared for different aspects within the structure, such as the maximum storey displacement, base shear, storey drift and storey shear, the structure is analyzed for seismic zone V and medium soil condition as per IS 1893:2002 using ETABS software. Results conclude that on sloping ground due to irregularity on ground surface, the structures are more vulnerable to earthquakes. Hence use of eccentric steel bracing is an effective and economical way to resist earthquake forces, Inverted V type bracing performs well compared to other bracing types. By using inverted V type bracing in step back buildings types maximum storey displacement of $70 \%$ and storey drift of $66 \%$ are obtained. Similarly for setback - step back configuration maximum storey displacement of $74 \%$ and storey drift of $70 \%$ are obtained respectively.
\end{abstract}

Keywords: X-Bracing, Diagonal Bracing, K-Bracing, V-Bracing and Inverted V Bracing

\section{INTRODUCTION}

Earth quakes are the natural phenomenon's which are caused by the release of large strain energy by the moving faults below the surface of the earth, which ultimately causes the shaking of the earth top surface in all possible directions with different amplitudes and intensities of lateral forces. Earthquake can be classified depending on the intensity of quake, duration and directions as minor, moderate and severe and is measured on the Richter magnitude scale. Anything above magnitude 7 is considered as severe type of quakes.

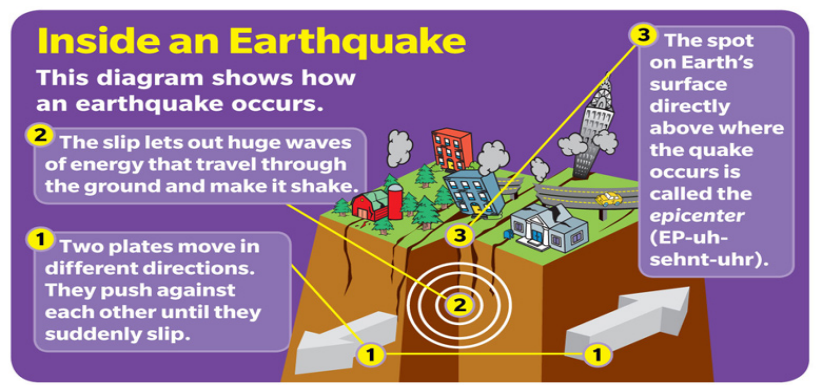

Fig 1. Earthquake Occurrences

Due to the industrial revolution, in the recent decade the growths in the cities have been on rise in incremental folds. Due to which the scarcity of plain topography land is a common problem in many cities, for this reason developers are often constructing multistory buildings to accommodate this rising population on sloping grounds. But with such provisions increase in self weight and live load along with lateral earthquake forces will increase and affect the buildings depending on many factors like strength of materials used, type of soil surface, amount of mass and stiffness of structural and non structural members, levels of workmanship, intensity of distribution of live loads during quake and also the response of the soil beneath the structure. Hence there is an urgent need to do a seismic assessment of the present structure in most urban area which comes under higher seismic zones to avoid the catastrophic events which recently caused in Nepal earthquake and assess seismic venerability of buildings which is an essential component of disaster management policy in India.

Seismic analysis is a method to carry out the response of the building structure during ground motions. It is a part of process structural design, which includes seismic assessments of the buildings and also the retrofitting measures to strengthen the retaining structure in the seismic regions. In recent days the buildings with irregular configurations in both plan and elevation are common. These buildings asymmetry will suffer severely during earthquakes and undergo coupled torsion and lateral motions. A building can be designed to be earthquake proof for a rare but strong earthquake proof, but such buildings will be more expensive. The most logical approach to seismic design problem is to accept the uncertainty of the seismic phenomenon. 
The analysis procedure teaches us how to identify the seismic forces and its demand. Depending upon the type of structure and its cost, the method of analyzing the structure varies from linear to non linear. The static non - procedure indicates which part of the building fails first and the elements begin to yield and deform in elastically as the load and displacement increases. Thus the resulting curve shows the capacity of the building and demand for the specific intensity of seismic forces, this resulting graph will generate a point on the curve where the capacity and demand will meet and we get a performance point. This point can be actually considered as the actual displacement of the structure in response to the specified lateral ground forces.

At last, this procedure gives the engineer a better understanding of the seismic characteristics of the structure and results in more logical and effective designs in future buildings and will be more economical for the retrofitting strategy of an existing building. The guidelines which recommends on these topics are ATC-40 and FEMA-356.

\subsection{Lateral Load Resisting Systems}

Lateral load resisting systems are used to resist the horizontal or lateral loads that are applied on the structure in the form of earthquake force or wind force.

\subsubsection{Types of Lateral Load Resisting Systems}

a) Moment resisting frame

b) In-fill frame

c) Shear wall

d) Tube system

e) Hybrid system

f) Braced frame

\section{OBJECTIVES}

The present work is aimed at evaluating $\mathrm{R} \mathrm{C}$ framed buildings with the following objectives

- To evaluate the response of multi-storied RC building structure with different bracing systems subjected to seismic loading and to identify the suitable bracing system for resisting the seismic load efficiently.

- Finding out the deflections \& storey drift at each storey using response spectrum method, equivalent static method, push over analysis and time history analysis method

- To observe the level of change of internal forces and storey drift for different types of braced models with the bare frame model.

- To investigate the seismic performance of a multistoreyed RC building with different bracing arrangements such as $\mathrm{X}$, inverted $\mathrm{V}, \mathrm{V}$, diagonals and $\mathrm{K}$ bracings using Nonlinear Static Pushover analysis method and Non-linear dynamic i.e. Time history analysis procedure.

\subsection{Modeling and Analysis Method}

- 3D modeling for analysis of $\mathrm{R} \mathrm{C}$ frame multistory building having different types of bracing systems using ETABS.

- The building is analyzed by Equivalent static, Response Spectrum and Pushover analysis.

- The building models are pushed along positive orthogonal directions.

\subsection{Parameters to be Studied}

- Base shear

- Storey shear

- Storey drift

- Storey displacement

- Performance point

\section{METHODOLOGY}

To study and evaluate the behavior of reinforce concrete buildings resting on the sloping ground. Here, a static, dynamic and a non-linear static analysis of a RC- building with fixed base is done considering different types of steel bracing frames using ETABS. In this analysis two different types of buildings are considered.

1. Step back building (Sloping ground)

2. setback - step back building (Sloping ground)

The linear and non-linear analysis of RC-frame building resting on sloping ground is been performed for zone $\mathrm{V}$ and medium soil as per FEMA-356 and ATC-40. In this analysis, the pushover analysis is performed by subjecting the building to a monotonically increasing pattern of later loads, which will represent the inertial forces experiencing by the structure when subjected to gradual ground shaking. Under this incrementally increasing load the structure will yield at certain point, thus the performance of the structure can be evaluated in this method.

\subsection{Software}

The software used for this analysis is ETABS 9.7 which stands for Earthquake three dimensional analysis of building system. It is an innovative structural analysis program developed to design and analyzes the structure under various lateral forces. Some of the advantages of ETABS are

$>$ The modeling process for most of the building configurations can be erected using simple grid system which is defined by the horizontal floors and vertical column lines with minimum effort.

$>$ Many of the floor system will be similar dimensions and properties, so by using similar storey option in edit grid data the structure will be erected with very less efforts.

$>$ The analysis parameters like storey drift, displacement, overturning moments and performance point of structure can be used for the design of the buildings.

\subsection{Analysis Considerations}

In the $3 \mathrm{D}$ analysis of various types of models following methods are studied 
- Equivalent static method

- Response spectrum method

- Non-Linear Static Analysis

\subsection{Description of Various Building Models}

For the particular study, the plan of the building is kept same for both step back and setback step back types of buildings.

\subsubsection{Step back building models}

Model 1: Building modeled as bare frame. However, masses of the $230 \mathrm{~mm}$ thick walls are included in the model.

Model 2: Building has inverted V bracings along the outer periphery of the step back type building.

Model 3: Building has $\mathrm{V}$ bracings along the outer periphery of the step back type building.

Model 4: Building has $\mathrm{K}$ bracings along the outer periphery of the step back type building.

Model 5: Building has X bracings along the outer periphery of the step back type building.

Model 6: Building has forward diagonal (/) bracings along the outer periphery of the step back type building.

\subsubsection{Setback - step back building models}

Model 7: Building modeled as bare frame. However, masses of the $230 \mathrm{~mm}$ thick walls are included in the setback - step back type building.

Model 8: Building has inverted V bracings along the outer periphery of the setback - step back type building.

Model 9: Building has V bracings along the outer periphery of the setback - step back type building.

Model 10: Building has $\mathrm{K}$ bracings along the outer periphery of the setback - step back type building.

Model 11: Building has $\mathrm{X}$ bracings along the outer periphery of the setback - step back type building.

Model 12: Building has forward diagonal (/) bracings along the outer periphery of the setback - step back type building.

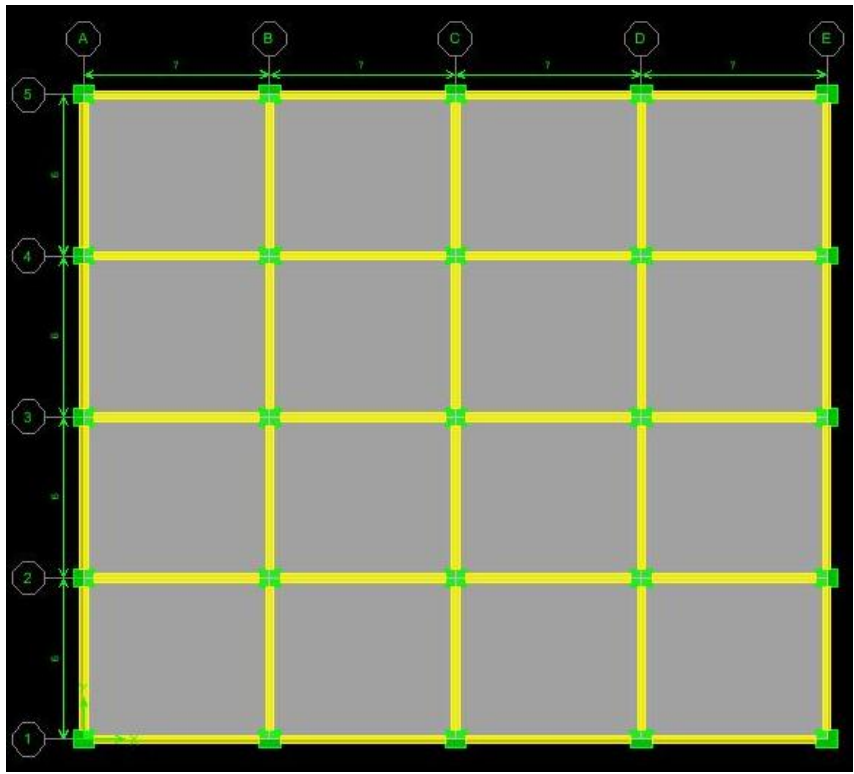

Fig 2. Plan Layout

All the considered building models have the same plan dimension $(28 \mathrm{~m} \times 24 \mathrm{~m})$. The models plan has four bays in each direction.

\section{RESULTS AND DISCUSSIONS}

In this chapter, the results of twelve selected building models are presented and discussed in detail. The results are included for all the different buildings models. The analysis of the different building models is performed by using ETABS analysis software.

In the present study the behavior of each model is captured and the results are tabulated in the form of base shear, lateral displacement and story drift in linear analysis. Where as in non linear, the performance of all the models are observed in terms of hinge formations and performance point. In non linear analysis, the pushover method is adopted and all the models are pushed using two different loading patterns in order to obtain plastic hinge and the critical performance point.

\subsection{Storey Displacement}

The maximum displacement for each floor level with respect to its ground is presented in tables obtained for equivalent static method (ESA) and response spectrum method (RSA) for step-back and step-back set-back types of building configurations with different types of bracing systems along both longitudinal (x-direction) and transverse (y-direction) are listed in the tables below and for better compatibility the displacements for each models are plotted in charts below. 


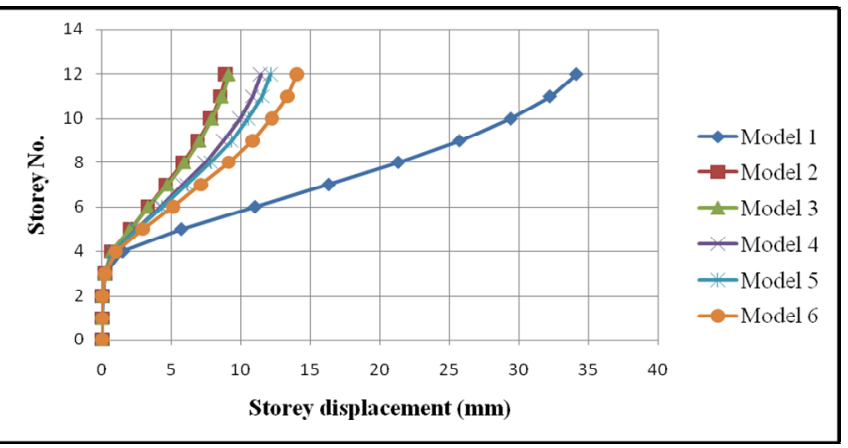

Fig 3. Comparison of storey Displacement for different stepback building models along longitudinal direction (ESA).

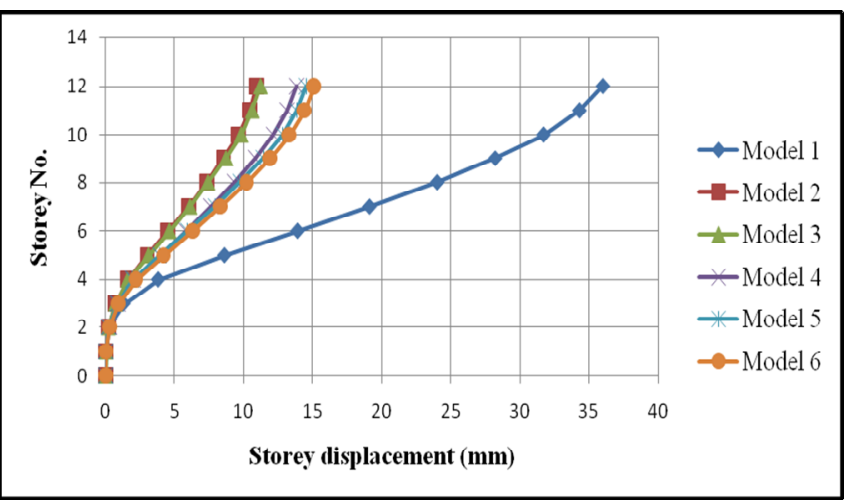

Fig 4. Comparison of storey Displacement for different stepback building models along transverse direction (ESA).

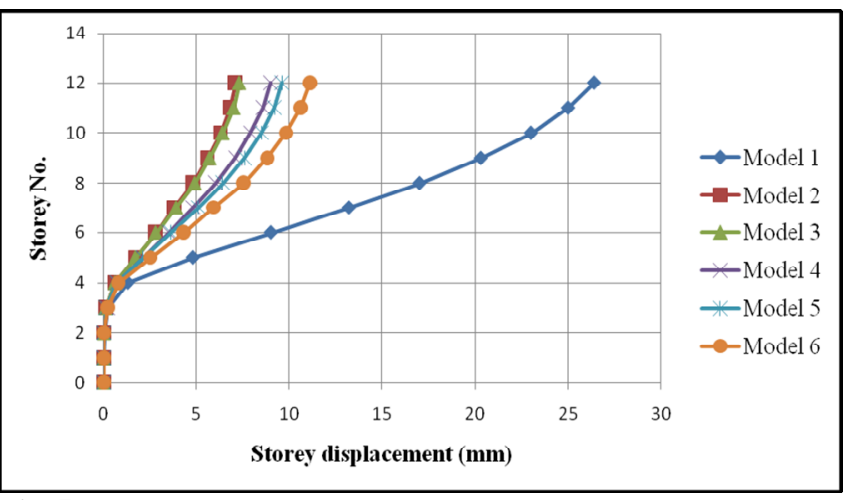

Fig 5. Comparison of storey Displacement for different stepback building models along longitudinal direction (RSA).

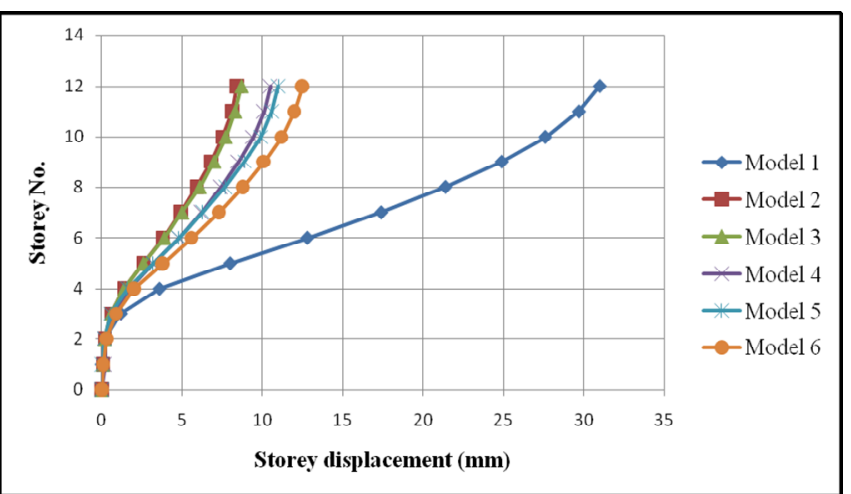

Fig 6. Comparison of storey Displacement for different stepback building models along transverse direction (RSA).

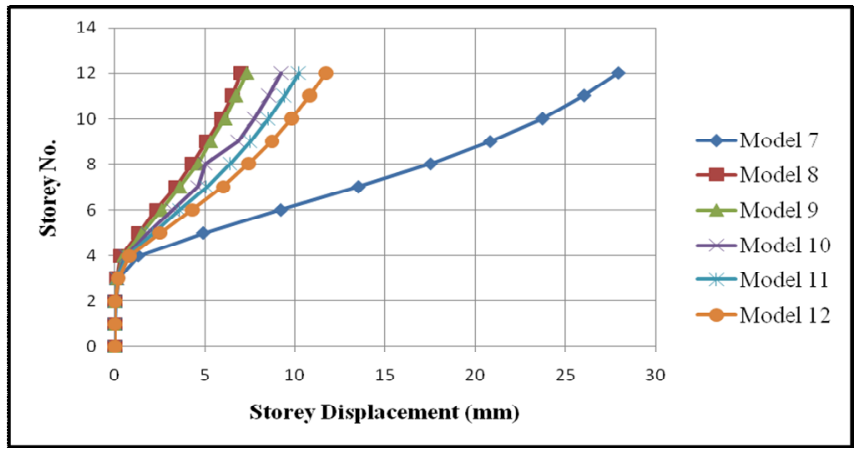

Fig 7. Comparison of storey Displacement for different set back -step back building models along longitudinal direction (ESA).

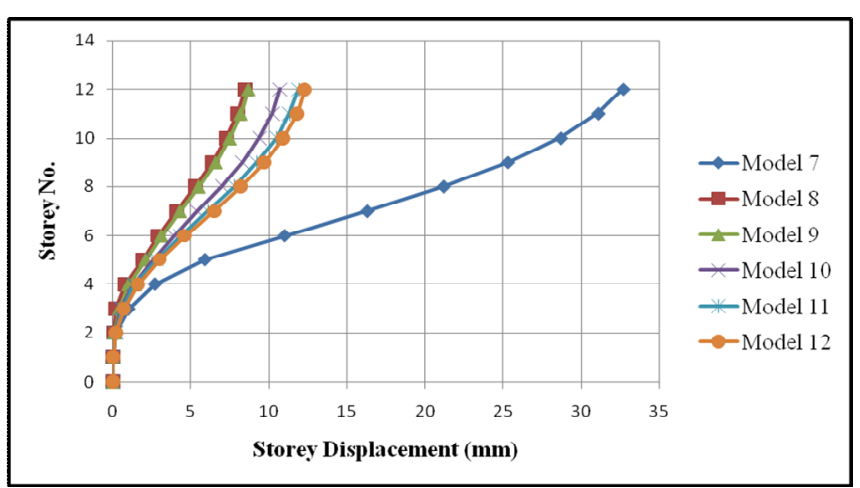

Fig 8. Comparison of storey Displacement for different set back - step back building models along transverse direction (ESA).

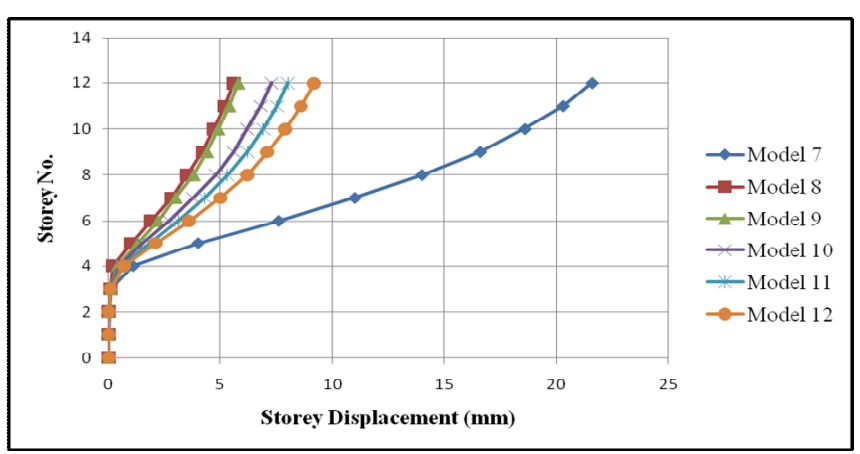

Fig 9. Comparison of storey Displacement for different set back - step back building models along longitudinal direction (RSA).

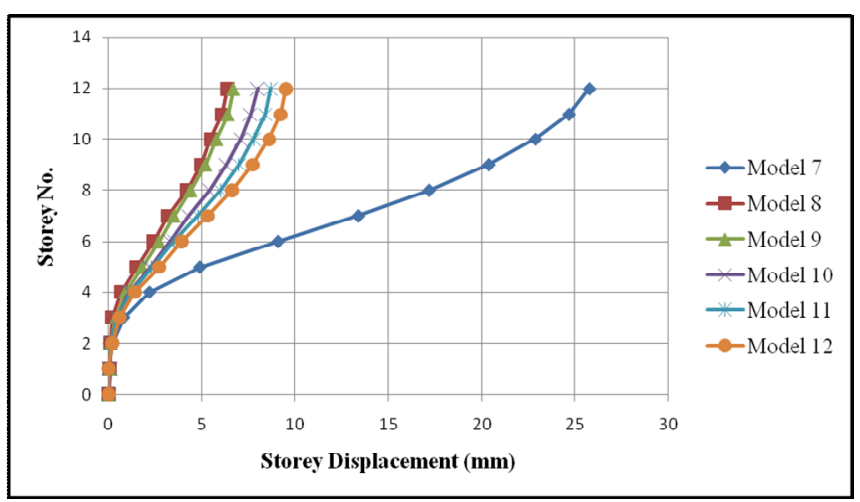

Fig 10. Comparison of storey Displacement for different set back - step back building models along transverse direction (RSA). 


\subsection{Storey Drift}

The permissible storey drift according to IS 1893-2002 : is limited to .004 times the storey height, so the minimum damage would take place during earth quake and pose less physiological fear in the minds of people. The maximum storey drift for step back configuration and setback - step back configuration buildings models along longitudinal and transverse direction obtained from ETABS are show in tables below.

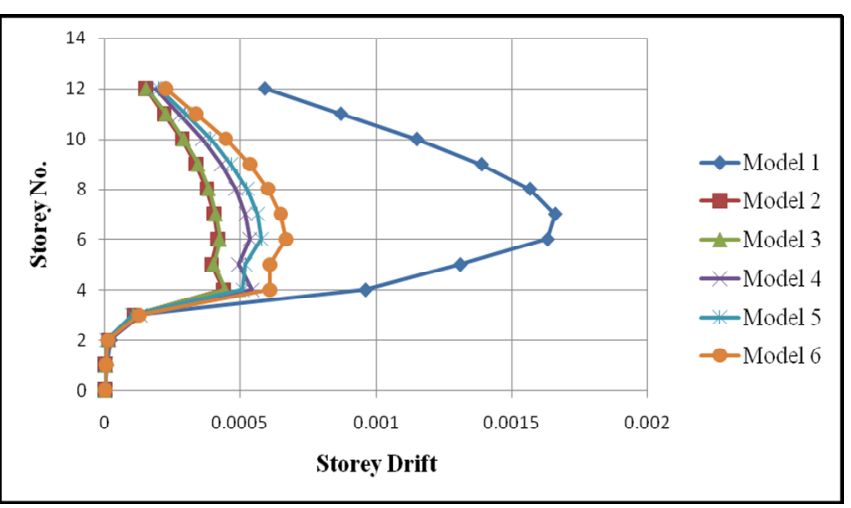

Fig 11. Comparison of storey Drift for different step-back building models along longitudinal direction (ESA).

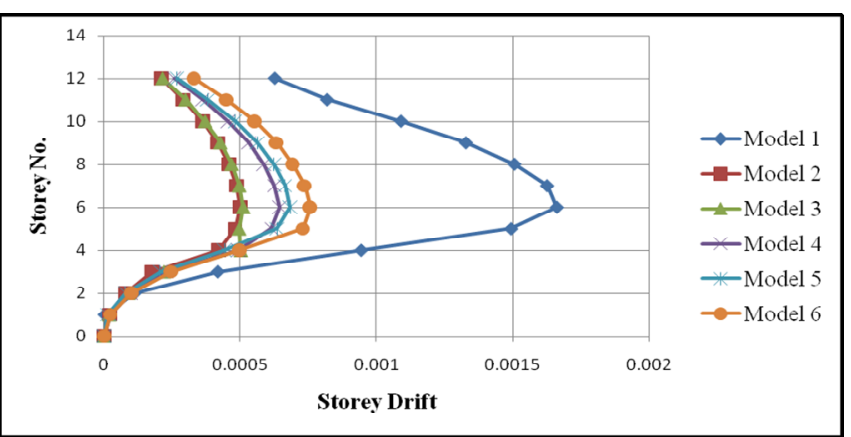

Fig 12. Comparison of storey Drift for different step-back building models along transverse direction (ESA).

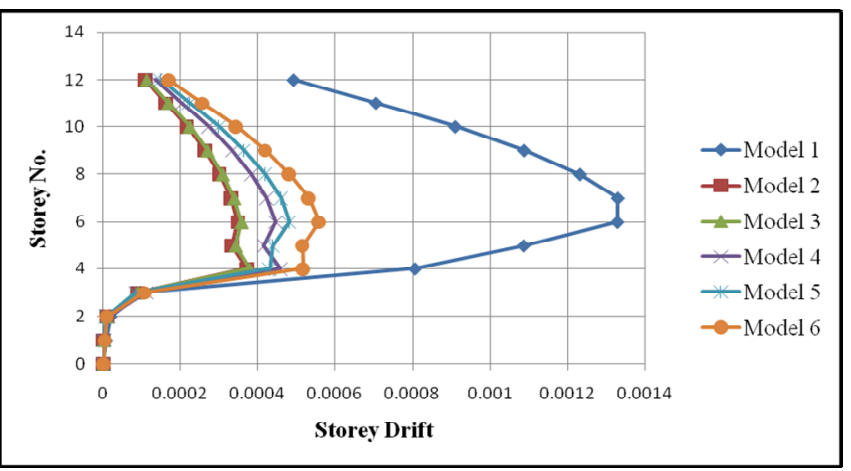

Fig 13. Comparison of storey Drift for different step-back building models along longitudinal direction (RSA).

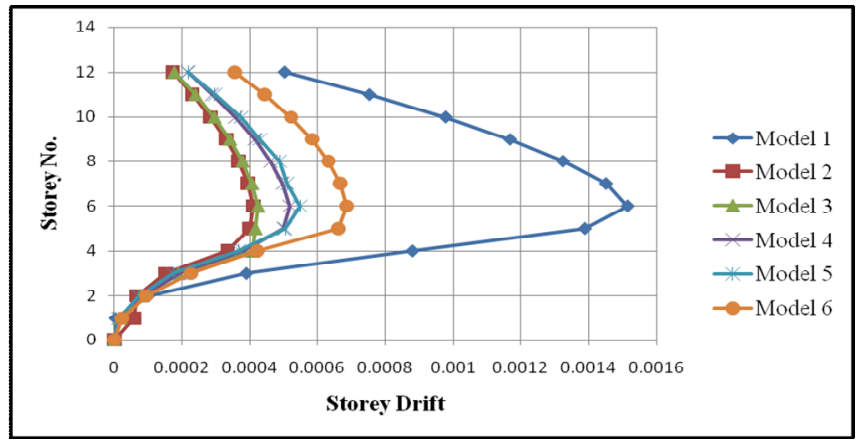

Fig 14. Comparison of storey Drift for different step-back building models along transverse direction (RSA).

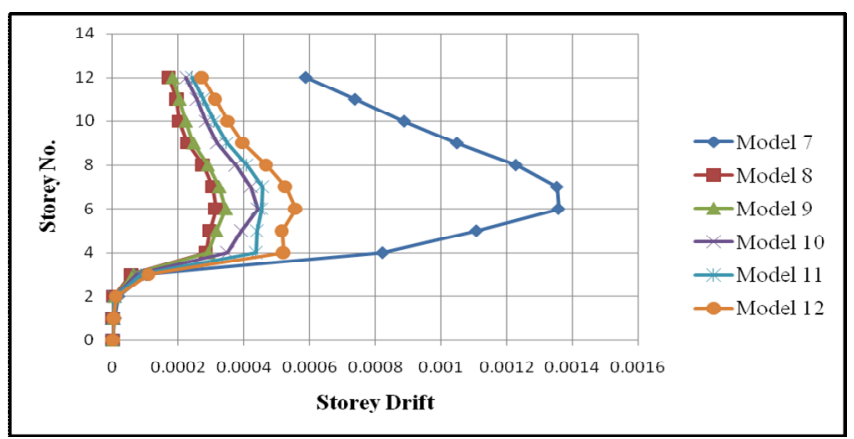

Fig 15. Comparison of storey Drift for different set back step back building models along longitudinal direction (ESA).

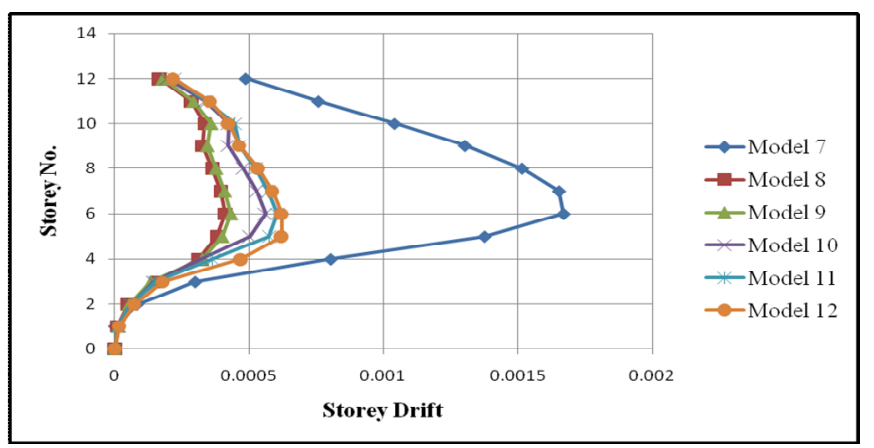

Fig 16. Comparison of storey Drift for different set back step back building models along transverse direction (ESA).

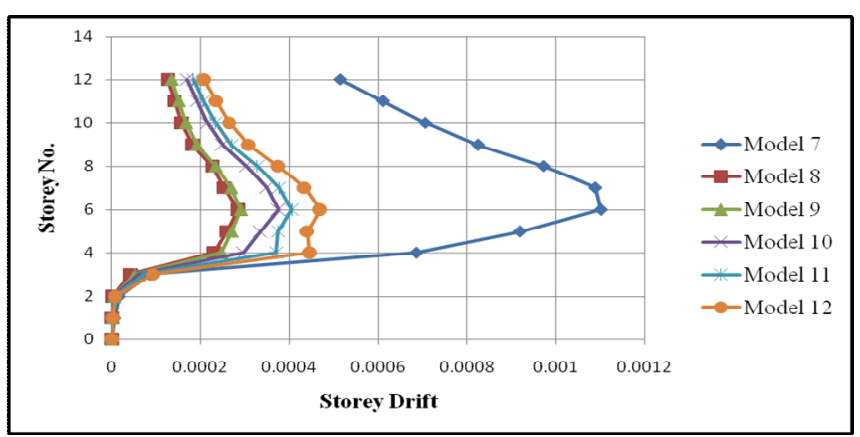

Fig 17. Comparison of storey Drift for different set back step back building models along longitudinal direction (RSA). 


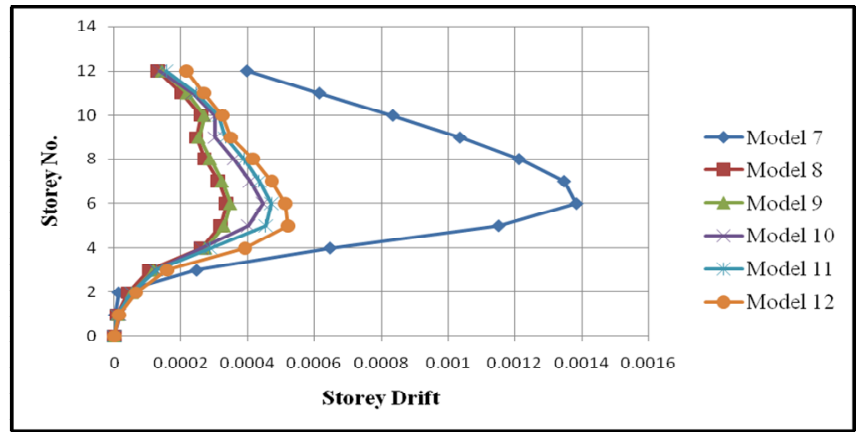

Fig 18. Comparison of storey Drift for different set back step back building models along transverse direction (RSA).

\subsection{Base Shear}

The base shear for Equivalent static method $\left(\mathrm{V}_{\mathrm{b}}\right)$ and the Response spectrum method $\left(\mathrm{V}_{\mathrm{B}}\right)$ as per IS 1893: 2002( Part I) for various building models are listed in the tables below. The scale factor $\mathrm{V}_{\mathrm{b}} / \mathrm{V}_{\mathrm{B}}$ has been multiplied as per clause 7.8.2 IS 1893:2002 (Part I)

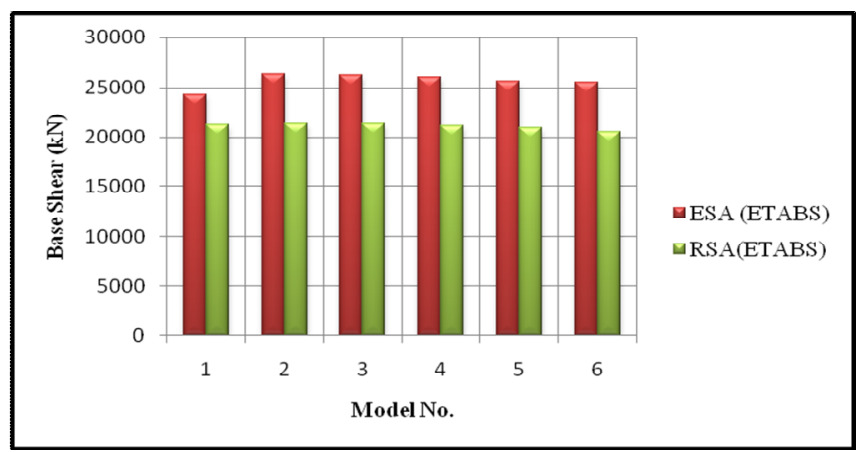

Fig 19. Model Vs Base shear for different step back models along longitudinal direction.

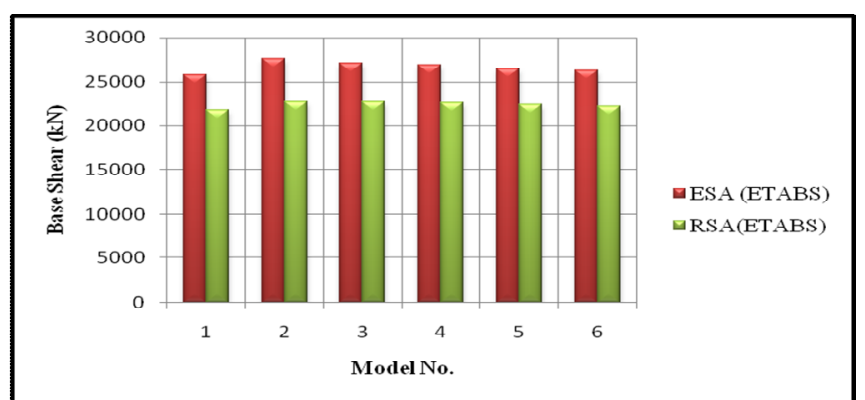

Fig 20. Model Vs Base shear for different step back models along transverse direction.

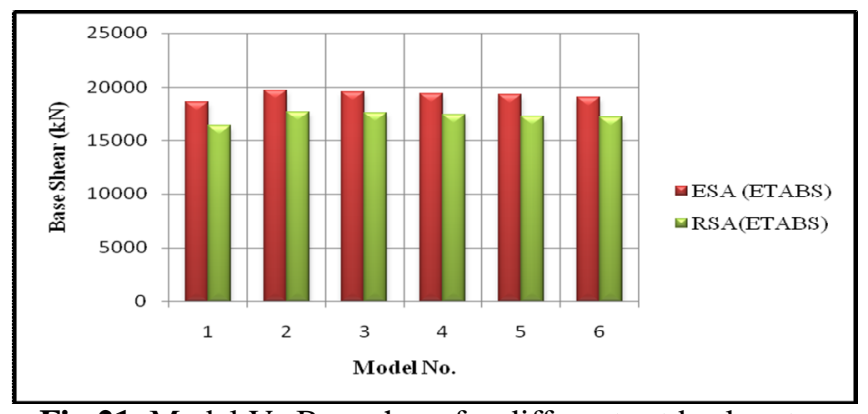

Fig 21. Model Vs Base shear for different set back - step back models along longitudinal direction.

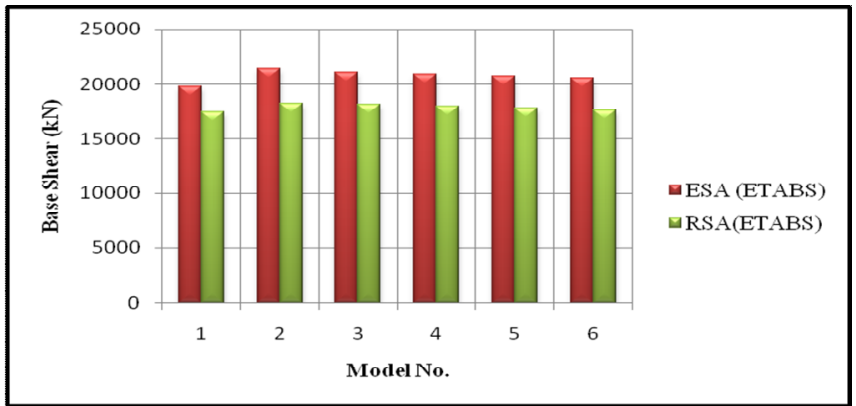

Fig 22. Model Vs Base shear for different set back - step back models along transverse direction.

\subsection{Push Over Analysis}

Pushover analysis for different sets of step back and setback - step back buildings configurations are analysed in this chapter using ETABS software, thus parameters like base shear, performance point, roof displacement, spectral acceleration (Sa) and spectral displacement are being considered.

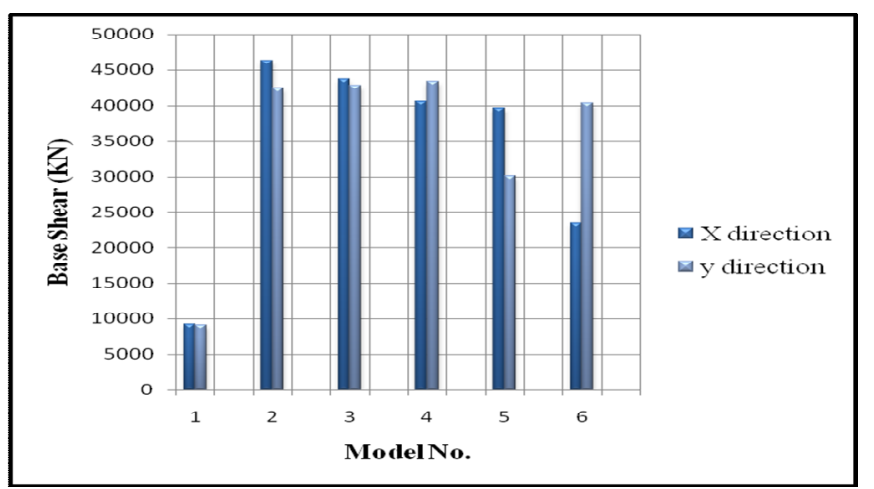

Fig 23. Comparison of base Shear at hinge for step back models along longitudinal direction and transverse direction.

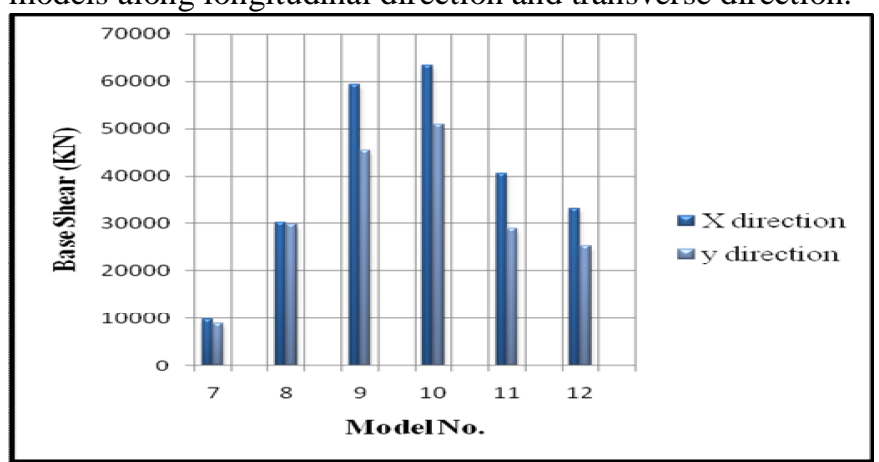

Fig 24. Comparison of base Shear at hinge for setback- step back models along longitudinal direction and transverse direction.

\subsection{Performance Point}

The seismic performance evaluation comprises of comparisons between some of the demand that earthquake places on the structure to measure the capacity of the building to resist. Base shear (total horizontal force at the lower level of the building) is normal parameter that is used for this purpose. The base shear demand that would be generated by a given earthquake or intensity of ground motion and compare this to capacity of the building. 
Table 1. Performance point parameters for step back models along longitudinal direction.

\begin{tabular}{|c|c|c|c|c|c|c|}
\hline Model No & 1 & 2 & 3 & 4 & 5 & 6 \\
\hline Spectral acceleration $\left.\mathbf{( S}_{\mathbf{a}}\right)$ & 0.119 & 0.476 & 0.471 & 0.427 & 0.423 & 0.379 \\
\hline Spectral Displacement $\left.\mathbf{( S}_{\mathbf{d}}\right)$ & 0.156 & 0.071 & 0.072 & 0.081 & 0.083 & 0.098 \\
\hline Base Shear (KN) & 6575.9 & 29660.2 & 29476.4 & 26850.3 & 25632.6 & 23727.73 \\
\hline Roof Displacement (mm) & 209 & 95 & 97 & 108 & 110 & 133 \\
\hline A-B & 1737 & 1694 & 1677 & 1743 & 1742 & 1639 \\
\hline B-IO & 241 & 506 & 532 & 491 & 440 & 538 \\
\hline IO-LS & 97 & 127 & 122 & 95 & 137 & 134 \\
\hline LS-CP & 244 & 5 & 5 & 1 & 9 & 22 \\
\hline CP-C & 0 & 0 & 0 & 0 & 0 & 0 \\
\hline C-D & 0 & 6 & 0 & 0 & 0 & 0 \\
\hline D-E & 15 & 2 & 2 & 2 & 2 & 1 \\
\hline TE & 0 & 0 & 0 & 0 & 0 & 0 \\
\hline Total no of hinges & 2334 & 2334 & 2334 & 2334 & 2334 & 2334 \\
\hline
\end{tabular}

Table 2. Performance point parameters for step back models along transverse direction.

\begin{tabular}{|c|c|c|c|c|c|c|}
\hline Model No & 1 & 2 & 3 & 4 & 5 & 6 \\
\hline Spectral acceleration $\left(\mathbf{S}_{\mathbf{a}}\right)$ & 0.116 & 0.533 & 0.450 & 0.405 & 0.392 & 0.374 \\
\hline Spectral Displacement $\left.\mathbf{( S}_{\mathbf{d}}\right)$ & 0.168 & .066 & .082 & .089 & .092 & .100 \\
\hline Base Shear (KN) & 6666.97 & 32810.9 & 29459.75 & 26740.42 & 24648.7 & 24559.2 \\
\hline Roof Displacement $(\mathbf{m m})$ & 214 & 88 & 106 & 112 & 117 & 139 \\
\hline A-B & 1695 & 1652 & 1567 & 1615 & 1736 & 1492 \\
\hline B-IO & 298 & 438 & 602 & 505 & 448 & 596 \\
\hline IO-LS & 108 & 143 & 155 & 195 & 131 & 168 \\
\hline LS-CP & 228 & 8 & 14 & 18 & 10 & 77 \\
\hline CP-C & 0 & 0 & 0 & 0 & 0 & 0 \\
\hline C-D & 0 & 0 & 0 & 0 & 0 & 0 \\
\hline D-E & 5 & 2 & 0 & 1 & 3 & 1 \\
\hline >E & 0 & 0 & 0 & 0 & 0 & 0 \\
\hline Total no of hinges & 2334 & 2334 & 2334 & 2334 & 2334 & 2334 \\
\hline
\end{tabular}

Table 3. Performance point parameters for set back - step back models along longitudinal direction.

\begin{tabular}{|c|c|c|c|c|c|c|}
\hline Model No & 7 & 8 & 9 & 10 & 11 & 12 \\
\hline Spectral acceleration $\left.\mathbf{( S}_{\mathbf{a}}\right)$ & 0.143 & 0.586 & 0.603 & 0.582 & 0.487 & 0.435 \\
\hline Spectral Displacement $\left.\mathbf{( S}_{\mathbf{d}}\right)$ & 0.123 & 0.056 & 0.059 & 0.061 & 0.068 & 0.081 \\
\hline Base Shear (KN) & 6440.90 & 28826.5 & 30612.72 & 27780.2 & 24553.44 & 22526.35 \\
\hline Roof Displacement $(\mathbf{m m})$ & 189 & 81 & 90 & 92 & 103 & 123 \\
\hline A-B & 1547 & 1364 & 1408 & 322 & 1504 & 1436 \\
\hline B-IO & 209 & 475 & 455 & 314 & 401 & 464 \\
\hline IO-LS & 62 & 176 & 186 & 104 & 138 & 140 \\
\hline LS-CP & 225 & 10 & 0 & 0 & 13 & 16 \\
\hline CP-C & 0 & 0 & 0 & 0 & 0 & 0 \\
\hline C-D & 0 & 0 & 0 & 0 & 0 & 0 \\
\hline D-E & 15 & 1 & 0 & 2 & 2 & 1 \\
\hline$>$ E & 0 & 0 & 0 & 0 & 0 & 0 \\
\hline Total no of hinges & 2058 & 2058 & 2058 & 2058 & 2058 & 2058 \\
\hline
\end{tabular}


Table 4. Performance point parameters for set back - step back models along transverse direction.

\begin{tabular}{|c|c|c|c|c|c|c|}
\hline Model No & 7 & 8 & 9 & 10 & 11 & 12 \\
\hline Spectral acceleration $\left.\mathbf{( S}_{\mathbf{a}}\right)$ & 0.142 & 0.536 & 0.532 & 0.523 & 0.456 & 0.433 \\
\hline Spectral Displacement $\left.\mathbf{( S}_{\mathbf{d}}\right)$ & 0.136 & 0.058 & 0.066 & 0.069 & 0.076 & 0.083 \\
\hline Base Shear $\mathbf{( K N )}$ & 6608.43 & 28476.42 & 27694.83 & 25483.66 & 232883.7 & 23150.36 \\
\hline Roof Displacement $(\mathbf{m m})$ & 215 & 97 & 101 & 103 & 114 & 127 \\
\hline A-B & 1390 & 1340 & 1344 & 868 & 1515 & 1242 \\
\hline B-IO & 364 & 574 & 564 & 396 & 429 & 536 \\
\hline IO-LS & 126 & 149 & 142 & 177 & 103 & 196 \\
\hline LS-CP & 177 & 28 & 20 & 0 & 6 & 43 \\
\hline CP-C & 0 & 0 & 0 & 0 & 0 & 0 \\
\hline C-D & 0 & 0 & 0 & 0 & 0 & 0 \\
\hline D-E & 1 & 2 & 1 & 0 & 0 & 1 \\
\hline >E & 0 & 0 & 0 & 0 & 0 & 0 \\
\hline Total no of hinges & 2058 & 2058 & 2058 & 2058 & 2058 & 2058 \\
\hline
\end{tabular}

\section{SUMMARY AND CONCLUSION}

\subsection{Summary}

The present work attempts to study the seismic response and performance level of symmetric RC building located in seismic zone-V. In this study all important components of the building that influence the mass, strength, stiffness and deformability of the structure are included in the analytical model. To study the behavior of different bracing systems at various locations in longitudinal and transverse direction. The deflections at different storey levels and storey drifts are compared by performing equivalent static and response spectrum method. The seismic performance level of the building models are obtained by performing non-linear static pushover analysis. The study leads to the following conclusions.

\subsection{CONCLUSIONS}

1. With the provision of different types of bracings, the storey drift and storey displacement gets reduced.

2. Models with inverted V bracings in longitudinal and transverse direction are found to be efficient against lateral seismic loading as they shows better performance in terms of strength and stiffness.

3. Storey drifts are found within the permissible limit as specified by IS1893-2002.

4. The performance of different building system are evaluated by pushover analysis procedure, for bare frame models the performance level is reaching to the ultimate collapse level, while models with $\mathrm{X}, \mathrm{V}$ and $\mathrm{K}$ bracings system models are within IO(immediate occupancy) to LS(life safety) region only.

5. By performing pushover analysis, the weak links and failure location can fairly be identified.

\section{REFRENCES}

[1] Vani Prasad, Nivin Philip "Effectiveness of Inclusion of Steel bracing in Existing RC Framed Structure",
International Journal of Research in Engineering \&Technology, Vol .2 Issue 9, sep 2014 (P. 81-88).

[2] Shivanand B, H.S Vidhyadhara "Design of 3D RC Frame on Sloping Ground", International Journal of Research in Engineering \& Technology, Vol .3 Issue 8 Aug 2014 ISSN 2321-7308

[3] Umesh .R.Biradar, Shivraj Mangalgi "Seismic Response of Reinforced Concrete Structure by using different Bracing System", IJRET, vol.3, Issue 09, Sep 2014 (P.422-426).

[4] Ajay K Sreerama, Pradeep Kumar Ramancharla "Earthquake behavior of reinforced concrete framed buildings on hill slopes" International Symposium on New Technologies for Urban Safety of Mega Cities in Asia, Report No:IIIT/TR/2013/-1.

[5] Nauman Mohammed, Islam Nazrul "Behaviour of Multistorey RCC Structure with Different Type of Bracing System", IJIRSET, Vol. 2 Issue 12, Dec 2013, ISSN 2319-8753.

[6] M.D. Kevadkar, P.B. Kodag, "Lateral Load Analysis of R.C.C. Building",International Journal of Modern Engineering Research (IJMER), Vol.3, Issue.3,MayJune. 2013 Pp-1428-1434 ISSN: 2249-6645.

[7] Kulkarni J.G, Kore P.N "Seismic Response Of Reinforced Concrete Braced Frames" International Journal of Engineering Research and Applications (IJERA), Vol. 3, Issue 4, Jul-Aug 2013, pp.1047-1053.

[8] C.M. Ravi Kumar, K.S. Babu Narayan, M.H. Prashanth, H.B Manjunatha and D.Venkat Reddy, "Seismic Performance Evaluation of RC Buildings With Vertical Irregularity", ISET Golden Jubilee Symposium Indian Society Of Earthquake Technology Department Of Earthquake Engineering Building IIT Roorkee, Roorkee, October 20-21, 2012, Paper No. E012.

[9] Y.Singh, phani Gade "Seismic Behavior of Buildings Located on Slopes - An Analytical Study and Some Observations From Sikkim Earthquake of September 18”, 2011, 15WCEE- LISBOA 2012. 
[10] R. Chiodi, A. Prota \& G. Manfredi "Nonlinear seismic behavior of an existing RC building retrofitted with BRBs", 15WCEE- LISBOA 2012.

[11] Madhusudan G. Kalibhat, Arun Kumar Y.M, Kiran Kamath, Prasad .S.K, Shrinath Shet, "Seismic Performance of R.C. Frames with Vertical Stiffness Irregularity from Pushover Analysis", IOSR Journal of Mechanical and Civil Engineering (IOSR-JMCE, EISSN: 2278-1684, P-ISSN: 2320-334X Pp 61-66.

[12] Viswanath K.G, Prakash K.B., Anant Desai,"Seismic Analysis of Steel Braced ReinforcedConcrete Frames",International Journal Of Civil And Structural Engineering, Volume 1, No 1, 2010 ISSN 0976 4399.

[13] Braz-César M. T., Barros R. C., "Seismic Performance of Metallic Braced Frames by Pushover Analysis", Compdyn 2009 Eccomas Thematic Conference On Computational Methods In Structural Dynamics And Earthquake Engineering M. Papadrakakis, N.D. Lagaros, M. Fragiadakis (EDS.) Rhodes, Greece, 2224 June2009.

[14] B.G. Birajdar, S.S. Nalawade "Seismic Analysis of Building Resting on Sloping Ground"13th World Conference on Earthquake Engineering Vancouver, B.C., Canada August 1-6, 2004 Paper No. 1472.

[15] A Ghobarah, H. Abou Elfath "Rehabilitation of a reinforced concrete frame using eccentric steel bracing" Engineering Structures 23 (2001) 745-755.

[16] Egor P. Popov, Michael D. Engelhardt "Seismic Eccentric Braced Frames" J.Construct Steel Research 10 (1988) 321-354.

[17] ATC 40 "Seismic evaluation and retrofit of concrete buildings" Volume 1,California seismic safety commission, California.

[18] IS: 456-2000., "Code of Practice for Plain and Reinforced Concrete", Bureau of Indian Standard, New Delhi, India.

[19] IS: 1893 - 2002 (Part 1), "Criteria for Earthquake Resistant Design of Structures”,part 1-General provisions and buildings, fifth revision, Bureau of Indian Standard, New Delhi, India.

[20] S.K.Duggal, "Earthquake resistant design of structures", Oxford university press, New Delhi.

[21] Indian Standard IS 800:2007, "General Construction in Steel- Code of Practice(Third Revision)", BIS New Delhi.

[22] SP: 6(1)-1964, "Handbook for Structural Engineers, Structural Steel Sections(Revised)”, BIS New Delhi. 